\title{
CRM PERFORMANCES ACCENTED WITH THE IMPLEMENTATION OF E-COMMERCE TECHNOLOGY
}

\author{
Ines Isaković* \\ Paneuropean University, Banja Luka, Bosna \& Hercegovina
}

Anywhere you live, you must have heard for e-commerce in last few years, because there are a lot of e-mails with a many advertisements with e-commerce purchasing. Maybe, you do not know exactly what e-commerce means. In my country, for sure, there are many persons that do not even heard about that opportunity for our economy, which Internet established as a part of business innovation. Because of that this paper is talking about e-commerce and datebases in details, as well as how it affect on the Customer Relationship Management.

Key words: Customer Relationship Management (CRM), E-commerce, Database

\section{INTRODUCTION}

Question is: What is precisely e-commerce? "Ecommerce (electronic commerce or EC) is the buying and selling of goods and services on the Internet, especially the World Wide Web. In practice, this term and a newer term, e-business, are often used interchangeably. For online retail selling, the term e-tailing is sometimes used [06]." According to the definition, e-commerce enables users to make transaction, that does not depend to geographical location and it enables users to visit site at any time we want. In the world many business companies have been selling online for years.

This kind of service is today essential for each company and government. E-commerce is based on the information systems but the user protection is the essential thing that needs to be done. The issue that attracts legislators is how to secure consumer in e-business, but that problem is solved by implementing e-signature.

E-commerce gives a lot of benefits for the business companies and makes their business more profitable and more effective. This way of transaction that can increase income. Anyone connected to the Internet is a potential customer, without looking where he/she is. This kind of business transaction is used all over the world. Not only to mention the effectiveness of e-commerce, there is a statistics that shows that 8-10 the biggest abundantly producing companies in the world have e-business functionality, 9-10 the most profitable companies and 10-10 those with the largest market validity have it also [08]. The customers are more comfortable to visit on-line stores because they can buy anything they want during 24 hours. As we all know, today people work too much and do not have enough time for finding things in which they are interested in. This kind of opportunity is an advantage for the buyer and seller, because it allows us banking, paying and booking.

There are different opinions concerning the future of e-commerce, but according to the situation today, development of e-commerce is in the stage of increasing. Furthermore, Fred Held said that "e-commerce and/or e-business has grown faster than all the predictions and will continue to grow. It is beginning to be part of the business.

Some applications, such as a bill paying over the Internet have been successful beyond anyone's imagination [07]. The future without e-commerce cannot be imagined. In the future every transaction to shops, business to business and government will go through the website.

E-commerce is buying or selling products and exchanging information through the web. This kind of service is becoming more and more popular in the world. To resolve the security problem it is necessary to make the law to protect users. Today, business without e-commerce cannot be imagined and we must follow all trends that world companies set in motion. E-commerce needs to be protected especially the business-to-customer marketing. 
Over the last twenty years business-to-business e-commerce has been presented and it enables companies to establish a good communication between their partners. Some benefits of this kind of communication are of a better quality and speed up information as well as costless transferring documents.

\section{CRM ON THE INTERNET}

Customer Relationship Management strategy on the Internet can be explained over three levels mentioned in [02] Anderson and Kerr book such as:

\section{Level one: Getting information out to customers}

On the Internet are all information about a company and products and services that it offers to existing and potential customers. Companies need to be aware of that that customer can find all positive opinions about the company; they also can find the negative once.

\section{Level two: Getting information back from customers}

Not having a purpose of only giving information to the customers also getting information about them and from them (collecting data about customers). Data about customer can be collected by enabling them to ask questions through mail, asking to register, or even putting a survey or a question of the day on site.

\section{Level three: E-commerce sales}

Use Internet in a purpose of selling and delivering products and services to the customers. Today, with IS technology company can sell products and services over the Internet, as well as reply to customer questions, offer additional products and services according to the previous purchases, and evaluate customers' satisfaction with your offerings. All these action can be done without being in touch with them in person. It is essential to provide real-time customer service support.

Customer service on the web site can be offered through following:

1. Search engines - support customers' need, by enabling them to quickly find needed information, which are located on the website.

2. Frequently Asked Questions (FAQs) - list of most commonly asked questions

3. Live help - customers are able to speak to a customer service representative. They visit the online site through Voice over Internet Protocol (VOIP) applications - enable PC users to click call button and directly communicate with company service.

4. Online order tracking - allow customers to track the progress of their order.

\section{THREE RULES FOR SUCCESS ON THE WAY TO E-COMMERCE}

After the implementation of e-commerce here are three rules for success related to which company must be aware of:

- E-commerce needs to be costless - implementation of e-commerce does not need to be expensive, maybe company can put an electronic catalogue on the web site and enable users to see offers.

- Data to be current and timely - information on the web site must be up-to-date.

- Make a great effort to keep it personal- be aware how companies web site will be accepted by customer side. The objective is to make customer life easier and better.
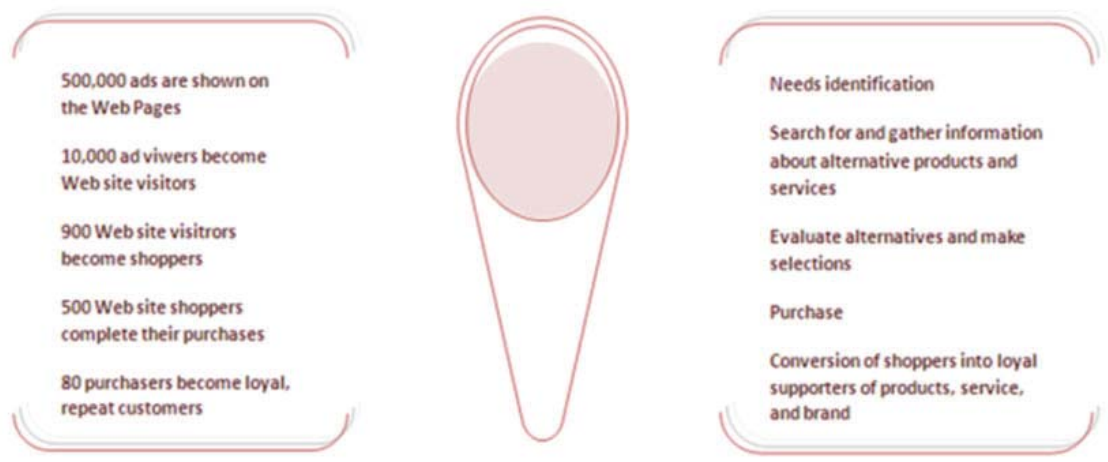

Funnel model of customer acquisition, conversion, and retention

Figure 1: Funnel model of customer acquisition, conversion, and retention 


\section{CUSTOMER ACQUISITION, CONVERSION, AND RETENTION: THE FUNNEL MODEL}

The job of marketing managers is to determine how the companies' customers will be acquired and retained. One way is by evaluating competing marketing strategies. The funnel model is the best tool used to understand a purpose of a marketing strategy that contains a clear structure for evaluating particular strategy elements. This model is less abstract and on the easiest way it represents the efficiency of two or more particular strategy. This model as many other models, starts with a huge amount of prospects, and few of them will be switch into serious prospect, then customers and finally loyal customers. One example of a Funnel Model is shown in Figure 1.

In this picture, the part that potential customers take as they become loyal, and repeated customers are presented on the left side of the figure, while on the right side of this figure is the rising increasing level of commitment that occurs in every step. In this model the wider the bottom of the funnel is, the better strategy is. That means that more prospects are converted into loyal customer.

Introduction of the Internet technology in the area of business leads to increase profitability and spread business around. Company needs to be aware of:

- Developing a real-world buying environment (shopping baskets with virtual shopping opportunities and engine to count visitors)

- Simplicity of e-commerce

- Security of customer data need to be explained to customers

- Speak with customers

- Personal data need to be treated with respect

\section{The Online Consumer}

E-commerce explains many electronic platforms, for instance the order from suppliers via electronic data interchange (EDI).

The customers that have 24 hours access to information on the Internet. Here is a list of things that they can do (1) obtained information about quality, features, prices, as well as costs; (2) arrange for advertising and information from producers and sellers that is important to start; (3) plan the offerings they want; and finally (4) employ shopping agents to look for and invite offers from many sellers. Customers determine information that they would like to have; offers they would like to have, and determine prices most suitable for their purchase.

\section{Online Marketing Benefits}

Three major advantages of online marketing are:

1. Order. The customers on the Internet have ability to order 24 hours a day

2. Availability of information. Customers can quickly and simply find needed information about products, competitors, companies, and so on

3. Fewer annoy. The customer is always right, and he/she do not have to deal with salespeople or wait in line

\section{Benefits to marketers}

- Ability to update product list and change prices

- Lower costs

- Relationship building

- Expansion in size of audience

\section{Advertising Online}

According to [05], advertisements that help company in promoting products and services to customers across the globe can be put on the Internet on three ways such as:

1. Determining the special parts in the major profitable online services

2. Choosing newsgroups

3. Ads that pop up when user surf on the web site, that contains pop-up windows banner ads, "tickers" (that represents banners moving across the screen), and "roadblocks" (these are ads that open as full screens and in order to see a site, user need to close it). Despite the banner ads, the "click-through rate" (represents users that click on an ad to get more information) has plunged under $1 \%$.

\section{E-mail}

The most beneficial method that company can use to link with a potential customer and current customers is through an e-mail. Using incoming e-mail, company can tell their customer that they can contact company via mail, if they have questions, suggestions or even complaints.

Furthermore, in direct marketing it is important to be aware of not building reputation as a "spammer." Spam is a mail that is unwelcome. In a 
where customers are angry as they are used to receive junk mails in their inbox, and due to that, even if they receive advertisement material they do not want to read it. Some countries want to established rules to forbid spam distribution. An efficient approach is to ask customer for permission before sending mail offers. Online marketing strategy is based on targeted visitors that have option to join a system of marketing messages. Companies that use this strategy have impressive response rates between 18 and $25 \%$ in comparison to the average banner ad's with the rate of $1 \%$ or even less.

\section{CUSTOMER DATABASE}

In order to establish a good relationship with customers and to successfully manage a business, first of all, the managers must know their customers and do database marketing. Consecutively, to know customers, the company needs to collect needed information about them and store them into database. Database "is a computer structure that houses a collection of related data. A database contains two types of data: end user data (row facts) and metadata. The metadata consist of data about data, that is, the data characteristics and relationship [04]." We need to agree that a database is an integrate part of CRM. A customer database is collection of thorough information about individual customers. As well as being existing, available and actionable for market intentions that it wants to achieve and lead to targeted age groups, sale of products and service, maintenance [03, 01]. One important process is a database marketing that represents the process of developing, maintaining and using customer databases for the purpose of getting in touch with customers, transaction and developing customer relationships [03].

\section{Data vs. Information}

The big deal is how companies collect, store, and manipulate with customer data in order to develop and implement more effective CRM strategy. Therefore, companies need first to decide what their strategy is, than start to search and collect data and information needed about the customers. Working together they are more effective and give us a great knowledge about customers.

According to [02] here is a list of information that company needs to know about their customer, no matter which business it do:
- How long customer does business with company?

- What do they mostly like about company?

-What is his/her opinion about the things that company could improve?

- How often they repurchase products?

-What life events influence their business with you? i.e., marriage, Internet etc.

- With which companies (competitors) he/she also do purchase?

- List of factors that influence his/her purchasing decision? That is a product price, quality, service and etc.

- What is the typical life cycle for each of your products and customers? (This tells company when the customer will be ready to buy again.)

\section{Data Collection}

Some of other ways how to collect customers' information are: from customer transaction, registration information, telephone queries and customer contact. Using online surveys, face-to-face or telephone interviews it is relatively easy to get data, because customers willing to give basic information about themselves. This lead to making our job harder, because we are dealing with a large amount of data according to which we need to make our decision related to the CRM strategy. Surveys are useful for getting data but also risky, because of possibility of asking the wrong questions. If the answers are essential for the business, than taking a surveys need to be given to a professional research firms. The key is to turn data into useful information, because data itself does not mean to us anything.

Front-line employees are important for collecting customer information and they represent company's interface for customers. In order to be productive company's front-line employees do not need to know all the details of customer relationship strategy, because this occasion can jeopardize company's customer relationship strategy. But what they need to have is a detailed answer and that will motivate them to be more productive and gather the information. The more informed they are, the more they will be able to motivate customer to provide information. 
Some tips how to prepare front-line employees to gather customer information:

- Inform them why company needs that data

- Prepare them on the possible customer questions about the request

- Make them prepared on the situation when customer does not want to give the information

- Do not make a pressure on employees to get information from customer that company is seeking, because some customers are not willing to participate

\section{Finding Meaning in Information}

Complementing customer data into information is a basic thing, because that is knowledge that we get by asking questions such as why and how. For example:

1. Why customer often decides to buy goods at lower price?

\section{How does customer view your service?}

In order to make major decisions such as service offerings, marketing and so on, information about customers that can tell us what are customers' needs, wants and what are their feelings about some of company's particular business areas. Data can enables user to discover trends.

\section{Creating Customer Database}

Even a simplest can store a multitude data about customer. That is fine if we know what we want to get, but the problem appears if database is used on the daily basis. The objective is to find information that will be effective for our operations and make customer comfortable customer databases to cooperate with your company. Company needs to have on its mind to keep customer privacy, not even to share all information with company's coworkers. In [02] a book of information about customer that will be shared with all of the employees, there are divisions into three types in a customer database:

\section{Important to know}

- Correctness of spelling customer's first and last name

- Essential to know customer's address and telephone number

- Essential to correct pronunciation of a customer's first and last name

- Essential to know which honorific to use - Mr., Ms., Miss, Mrs. or Dr

\section{Nice to know}

- How the customer paid for products

- How long the person has been a customer

- How much persons from a particular firm or household places make order

- Ordinary customer's purchases

- Last products that the customer purchased

- Customer's complaints if he/she has it

\section{Not for general knowledge}

- The customer's age

- The level of customer's income

- The customer's marital status and number of children

- The level of customer's education

- Some of answers that are related to the typical survey questions and which are developed in order to find out opinion about the company and its products and services

Those data are stored into database and need to be up to time and valuable in order to get timely and useful knowledge from database.

To make clear, company can only use the information getting from a customer for the purpose it has told him or her. Company is not able to sell that information to other company or use it for future research projects unless it has asked for the customer's permission.

\section{Usage of the database}

The following section will show five ways in which database can be useful:

\section{Use of the database in order to identified} forecasts. Many companies' use advertisement as a tool of increases their profits. Usually, the ads have a response feature like a free phone number or business replay card. According to these responses the database is developed. Furthermore, the company did a search through database to find potential customers, and then contact them by e-mail, telephone or personal call in order to turn them into customers.

2. Use of the database to find out customers that should get a current product. Selling, up-selling and cross-selling are types of the sell that are companies interested for. They also set up criteria for the targeted customers for a current product. Furthermore, companies search their database to see which customers are more likely to be their ideal 
type. If targeted customers do not respond than company need to offer a special discount rate.

3. Use of the database in order to build stronger customer loyalty. A customer loyalty is one of the essential tasks for each company. It can be accomplished by building customer's interest and enthusiasm. The major question is how to do that? Remember customer performance by sending gifts, giving discount rates and sending interesting reading material.

4. Use of database in order to establish reactive customer buying. Each customer likes when companies where they usually buy products to remember them for the Christmas shopping or off-season promotions. Companies can by installing automatically mailing programs to send birthday or jubilee cards to their customer. That represents a great gesture. And in that case the database can help company to develop attractive or timely offers.

5. Use of the database in order to keep away from serious customer mistakes. Depending on the type of the business, mistakes can be different. For example, in post office, database can give notification that some customers did not pay the last bill even it is not true. System automatically sends that notification to the employee in order to inform that customer. Employee that does not know if the customer paid bill or not, he/she sent these notifications (in a form of the bill) that came from database to the customer, and in that case customer is angry and may charge the company.

\section{The Disadvantage of Database Marketing and CRM}

Talking about advantages of database marketing is not appropriate if we even do not determine disadvantages, which also reflect on CRM. Four reasons discourage company from effectively implementing CRM. The first thing is cost of building and maintaining customer database, because in order to do that company need computer hardware, database software, communication links, analytical programs and skilled personnel. It is hard to collect the right data about individual customers. There are some cases where customer database will not be useful:
- Product that is purchased once

- Less loyalty that customer shows to a brand

- Number of sold products is too small

- Cost of gathering information is too high

The second thing is the ability to have customeroriented employees and use of available information. Employees found out that dealing with customer relationship marketing is much harder then dealing with traditional transaction marketing. Successful database marketing includes employee performance and also their training and development as well as dealers and supplies.

The third thing is that there are some customer that are not interested in relationship with company, and feeling upset, as they think that company collect too much personal information, which are secure and private, and are just for company usage.

The fourth thing is that assumptions that CRM represents are not always true. In order to support this statement, better way is to use example such as loyal customers are not always cost less.

In order to have beneficial database marketing company needs to have costs that come from collecting customer data, maintaining and mining data. Yet, when it works, a data warehousing yields more than costs. Database marketing is used by the companies that can easily collect customer data such as hotels, airlines, banks and so on. Other companies that can get benefices from CRM are companies that do a lot crossselling and up-selling as well as companies with different customers' needs. In some cases such as low customer lifetime value (CLV), where not direct contact between seller and buyer is, CRM is not beneficial. [08] There are four main dangerous of CRM listed in their book:

1. First decide what a customer strategy is, and then implement CRM

2. Launching CRM before changing organization to match

3. Presume that more CRM technology is better

\section{Stalking, not wooing customer}

All these facts are needed in order to decide how much to spend on developing and using of database marketing to get in touch with company's customer relationships. So, the second important part is: the data warehousing that comprised of a conventional data warehouse and an operational data store. 


\section{CONCLUSION}

E-commerce is buying or selling products and exchanging of information trough the web. This kind of service is becoming more and more popular in the world. E-commerce enables a lot of benefits for the business companies and makes their business more profitable and more effective. This globalization in the entire economy makes organizations to act as the rivals and it has also an impact on a customer's demand, but what they discovered is that treating the existing customer well is better than finding new ones. That means that the most important assets of each organization is a long-term relationship with customers that can lead to greater profitability, the customer's and company's satisfaction and loyalty. The organizations cannot escape this revolution, because it is present and it is business-to-business marketing revolution. Each level of the company will be affected, but some of the company managers will follow new trends and some of them will refuse changes and the role of the new technology. However, to avoid misunderstanding, the implementation of the Customer Relationship Management (CRM) will not be an easy process, and the fact is that organizations that don't accept those changes will lose a competitive advantage.

\section{REFERENCES}

1) Aleksić-Marić, V., Stojanović, D. (2007): Rešavanje sigurnosnih rizika u elektronskom poslovanju i informaciona ekonomija, Journal of Applied Engineering Science (Istraživanja i projektovanja za privredu), No. 16, pp. 53-61

2) Gary P. Schneider, 2006, Electronic Commerce, Sixth Annual Edition, Course Technology, Canada, page 185

3) K. Anderson and C. Kerr, Customer Relationship Management. United States of America: McGraw-Hill, 2002. [Online]. Available:http:// www.briefcasebooks.com/andersonfm.pdf. [Accessed April 28, 2008].

4) P. Kotler and K. L. Keller, Marketing Management, 12 ed. United States of America: Pearson Education, Inc., 2006.

5) P. Rob and C. Coronel, Database Systems: Design, Implementation and Management, 6 ed, United States of America: Course Technology, 2004

6) Philip Kotler, Marketing Management, $10 \mathrm{Ed}$, United States of America: Pearson Custom Publishing, 2002. [Online]. Available:http://ebooks-for everyone.blogspot.com/2007/08/ marketing-management-millenium-edition. html. [Accessed April 30, 2008].

7) Primode, "Information Security Glossary". [Online].Available:http://www.google.ba/ url?sa=X\&start=0\&oi=define \&q=http://www. primode.com/glossary.html. [Accessed May 27, 2008].

8) R. Shaik, "The Future of eCommerce", 2001. [Online]. Available:http://www.ipowerweb. com/profit/articles/20024.htm. [Accessed May 28, 2008].

9) UNDP Bosnia and Herzegovina, ICT for Development, e-poslovalje Trening film, Developing the information Society of Bosnia and Herzegovina, 2 ed.

Paper sent to revision: 20.08.2013.

Paper ready for publication: 12.09.2013. 